\title{
Carbohydrates and fat for training and recovery
}

\author{
LOUISE M. BURKE, ${ }^{1 *}$ BENTE KIENS ${ }^{2}$ and JOHN L. IVY ${ }^{3}$ \\ ${ }^{1}$ Department of Sports Nutrition, Australian Institute of Sport, PO Box 176, Belconnen, ACT 2616, \\ Australia, ${ }^{2}$ Department of Human Physiology, Copenhagen Muscle Research Centre, Institute of Exercise and Sports \\ Sciences, University of Copenhagen, DK-2100, Copenhagen Ø, Denmark and ${ }^{3}$ Department of Kinesiology and Health \\ Education, University of Texas, Austin, TX 78747, USA
}

Accepted 7 August 2003

\begin{abstract}
An important goal of the athlete's everyday diet is to provide the muscle with substrates to fuel the training programme that will achieve optimal adaptation for performance enhancements. In reviewing the scientific literature on post-exercise glycogen storage since 1991, the following guidelines for the training diet are proposed. Athletes should aim to achieve carbohydrate intakes to meet the fuel requirements of their training programme and to optimize restoration of muscle glycogen stores between workouts. General recommendations can be provided, preferably in terms of grams of carbohydrate per kilogram of the athlete's body mass, but should be fine-tuned with individual consideration of total energy needs, specific training needs and feedback from training performance. It is valuable to choose nutrient-rich carbohydrate foods and to add other foods to recovery meals and snacks to provide a good source of protein and other nutrients. These nutrients may assist in other recovery processes and, in the case of protein, may promote additional glycogen recovery when carbohydrate intake is suboptimal or when frequent snacking is not possible. When the period between exercise sessions is $<8 \mathrm{~h}$, the athlete should begin carbohydrate intake as soon as practical after the first workout to maximize the effective recovery time between sessions. There may be some advantages in meeting carbohydrate intake targets as a series of snacks during the early recovery phase, but during longer recovery periods $(24 \mathrm{~h})$ the athlete should organize the pattern and timing of carbohydrate-rich meals and snacks according to what is practical and comfortable for their individual situation. Carbohydrate-rich foods with a moderate to high glycaemic index provide a readily available source of carbohydrate for muscle glycogen synthesis, and should be the major carbohydrate choices in recovery meals. Although there is new interest in the recovery of intramuscular triglyceride stores between training sessions, there is no evidence that diets which are high in fat and restricted in carbohydrate enhance training.
\end{abstract}

Keywords: carbohydrate, energy intake, glycaemic index, glycogen, performance.

\section{Introduction}

An important goal of the athlete's everyday diet is to provide the muscle with substrates to fuel the training programme that will achieve optimal adaptation and performance enhancements. Body fat and carbohydrate stores provide the major sources of exercise fuel; whereas fat sources (plasma free fatty acids derived from adipose tissue and intramuscular triglycerides) are relatively plentiful, carbohydrate sources (plasma glucose derived from the liver or dietary carbohydrate intake, and muscle glycogen stores) are limited (for a review, see Coyle, 1995). In fact, the availability of carbohydrate as a substrate for the muscle and central nervous system becomes a limiting factor in the performance of

\footnotetext{
* Author to whom all correspondence should be addressed.

e-mail: louise.burke@ausport.gov.au
}

prolonged sessions ( $>90 \mathrm{~min}$ ) of submaximal or intermittent high-intensity exercise, and plays a permissive role in the performance of brief high-intensity work. As a result, sports nutrition guidelines have focused on strategies to enhance body carbohydrate availability. Such practices include intake of carbohydrate before and during a workout to provide fuel for that session, as well as intake of carbohydrate after the session and over the day in general to promote refuelling and recovery (for a review, see Hargreaves, 1999).

Although other reviews in this issue will discuss strategies for promoting carbohydrate availability before (Hargreaves et al., 2004) and during exercise (Coyle, 2004) in relation to the enhancement of competition performance, these practices should also be integrated into the athlete's training diet. The focus of this article, however, is successful refuelling from day to day, to recover between the daily sessions or multiple workouts 
undertaken in the athlete's training programme. Strategies to achieve these goals will be particularly important for the serious athlete whose fuel requirements for everyday training are likely to challenge or exceed normal body carbohydrate stores. Key issues related to carbohydrate intake for training and recovery raised in the 1991 position stand on nutrition for sport (Devlin and Williams, 1991) are summarized in Table 1. The aim of this article is to review areas in which these guidelines have been changed or updated.

\section{Update on post-exercise glycogen recovery}

The application of the biopsy technique to the study of exercise metabolism in the 1960s allowed sports scientists to measure directly the glycogen content of

Table 1. Summary of 1991 guidelines for carbohydrate needs for training and recovery (Devlin and Williams, 1991)

\section{Stated guidelines}

- In the optimum diet for most sports, carbohydrate is likely to contribute about $60-70 \%$ of total energy intake.

- After each bout of exercise, the diet should contain sufficient carbohydrate to replenish the glycogen stores and to maximize subsequent performance. The requirement for sugar and starches, in both solid and liquid forms, will vary, depending on the timing and nature of the physical activity.

- Carbohydrate intake after exhaustive exercise should average $50 \mathrm{~g}$ per $2 \mathrm{~h}$ of mostly moderate and high glycaemic carbohydrate foods. The aim should be to ingest a total of about $600 \mathrm{~g}$ in $24 \mathrm{~h}$.

Additional or underpinning information (Coyle, 1991)

- After exhaustive exercise, muscle glycogen synthesis needs of $\sim 100 \mathrm{mmol} \cdot \mathrm{kg}^{-1}$ occur at an average rate of $\sim 5 \mathrm{mmol} \cdot \mathrm{kg}^{-1} \cdot \mathrm{h}^{-1}$, requiring $\sim 20 \mathrm{~h}$ for recovery (normalization) of glycogen stores.

- The intake of carbohydrate in the first $2 \mathrm{~h}$ after exercise allows a somewhat faster rate of glycogen synthesis (i.e. 7$8 \mathrm{mmol} \cdot \mathrm{kg}^{-1} \cdot \mathrm{h}^{-1}$ ) than normal. The athlete should ingest sufficient carbohydrate as soon after exercise as is practical, the most important reason being to start recovery as soon as possible and maximize the time for glycogen synthesis.

- Glycogen synthesis over the day is similar whether carbohydrate is consumed as large meals or as a series of smaller snacks.

- There is no difference in glycogen synthesis when liquid or solid forms of carbohydrate are consumed; however, practical issues may dictate the choices of athletes.

- Carbohydrate-rich foods with a moderate to high glycaemic index provide a readily available source of carbohydrate for muscle glycogen synthesis. Carbohydrate-rich foods with a low glycaemic index should not make up more than a third of recovery meals. isolated muscle samples, and thus determine the factors that enhance or impair storage of this important fuel. Since 1991, techniques involving nuclear magnetic resonance spectroscopy have also become available to provide a non-invasive estimate of muscle glycogen content (Roden and Shulman, 1999), and have increased the practical opportunities to study such factors.

A new dimension to the literature on glycogen synthesis and utilization is the discussion of the presence of two glycogen pools within muscle, proglycogen and macroglycogen (Adamo and Graham, 1998). Initially, these were thought to be separate and metabolically distinct compounds (Shearer and Graham, 2002), but the current understanding is that they probably represent the extremes of a spectrum of glycogen molecules of different size. Studies have isolated a primer for glycogen synthesis, the protein glycogenin, which acts both as the core of the glycogen molecule and the enzyme stimulating self-glycosylation (Alonso et al., 1995). The initial accumulation of glucose units to glycogenin forms proglycogen, which is of relatively smaller size. Proglycogen storage is most prominent during the first phase of recovery and is sensitive to the provision of dietary carbohydrate (Adamo et al., 1998). During the second phase of glycogen recovery, glycogen storage occurs mainly in the pool of macroglycogen: a glycogen molecule with greater amounts of glucose relative to the glycogenin core. An increase in the macroglycogen pool appears to account for glycogen supercompensation in the muscle after 2-3 days of high carbohydrate intake (Adamo et al., 1998). Future studies may allow us to exploit this information, and determine new factors and strategies that enhance the metabolic availability of glycogen pools or increase storage. In the meantime, however, we will consider glycogen as a generic storage form for carbohydrate within the muscle and liver, and discuss the factors that influence restoration of glycogen following exercise depletion.

\section{Amount of dietary carbohydrate}

Typically, the most important dietary factor affecting muscle glycogen storage is the amount of carbohydrate consumed. Data from various studies that have monitored muscle glycogen storage after $24 \mathrm{~h}$ of recovery from glycogen-depleting exercise are summarized in Fig. 1, plotting glycogen storage against dietary carbohydrate intake. Despite differences between study methodologies such as the calibre of the athletes, the size of their active muscle mass and type of carbohydrate feedings, these data suggest that there is a direct and positive relationship between the quantity of dietary carbohydrate and post-exercise glycogen storage, at 


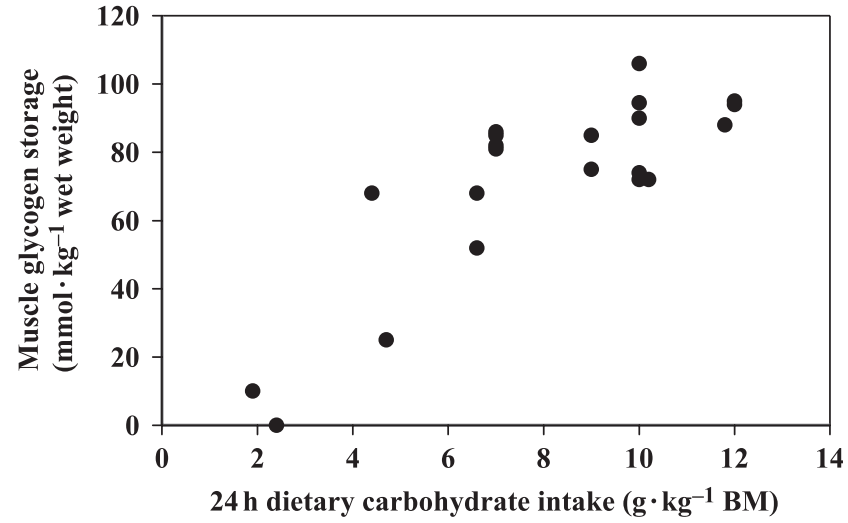

Fig. 1. Amount of carbohydrate intake and muscle glycogen storage. The relationship between daily carbohydrate intake and muscle glycogen storage during $24 \mathrm{~h}$ of passive recovery from glycogen-depleting exercise is plotted from data taken from Burke et al. (1993, 1995, 1996, 2003), Costill et al. (1981), Kiens and Richter (1998), Parkin et al. (1997) and Starling et al. (1997). Taken together, these data suggest an increase in glycogen storage with increasing dietary carbohydrate intake, until the muscle storage threshold is reached.

least until the muscle storage capacity or threshold has been reached. Only two studies have directly investigated this relationship by feeding different amounts of carbohydrate to trained individuals over a 24 -h recovery period; the results of these studies show an increase in glycogen storage with increasing carbohydrate intake and a glycogen storage threshold at a daily carbohydrate intake of around $7-10 \mathrm{~g} \cdot \mathrm{kg}^{-1} \mathrm{BM}$ (where $\mathrm{BM}=$ body mass) (Costill et al., 1981; Burke et al., 1995).

Although these figures have evolved into the recommended carbohydrate intakes for optimal muscle glycogen recovery, it is worth noting that they are derived from studies of glycogen storage during a passive recovery period. As a result, requirements for total daily carbohydrate intake may be lower for athletes whose training programmes do not challenge daily glycogen stores, but may also be higher for some individuals or some situations. For example, athletes who undertake strenuous training or competition programmes may also need to meet the daily fuel requirements of their continued exercise in addition to post-exercise recovery. For example, well-trained cyclists undertaking $2 \mathrm{~h}$ of training each day were found to have higher muscle glycogen stores after a week of a daily carbohydrate intake of $12 \mathrm{~g} \cdot \mathrm{kg}^{-1} \mathrm{BM}$, than when consuming the 'recommended' carbohydrate intake of $10 \mathrm{~g} \cdot \mathrm{kg}^{-1} \mathrm{BM} \cdot \mathrm{day}^{-1}$ (Coyle et al., 2001). Furthermore, Tour de France cyclists riding at least $6 \mathrm{~h}$ each day have been reported to consume carbohydrate intakes of $12-13 \mathrm{~g} \cdot \mathrm{kg}^{-1} \mathrm{BM} \cdot \mathrm{day}^{-1}$ (Saris et al., 1989). Increased carbohydrate intake may also be useful in the case of muscle damage (e.g. after eccentric exercise), which typically impairs the rate of postexercise glycogen resynthesis. Costill and co-workers (1990) reported that low rates of glycogen restoration in damaged muscles might be partially overcome by increased amounts of carbohydrate intake during the first $24 \mathrm{~h}$ of recovery.

The 1991 guidelines for carbohydrate intake during the first $4-6 \mathrm{~h}$ of recovery (viz. $\sim 1 \mathrm{~g} \cdot \mathrm{kg}^{-1} \mathrm{BM}$ every $2 \mathrm{~h}$ ) are based on studies that failed to find differences in post-exercise glycogen storage following carbohydrate intakes of 0.7 and $1.4 \mathrm{~g} \cdot \mathrm{kg}^{-1} \mathrm{BM}$ (Blom et al., 1987), or between 1.5 and $3.0 \mathrm{~g} \cdot \mathrm{kg}^{-1} \mathrm{BM}$ (Ivy et al., 1988b), fed at intervals of $2 \mathrm{~h}$. However, more recent investigations of feeding during the first $4 \mathrm{~h}$ of recovery (Doyle et al., 1993; Piehl Aulin et al., 2000; van Hall et al., 2000) have achieved glycogen synthesis rates of up to $10-11 \mathrm{mmol} \cdot \mathrm{kg}^{-1} \mathrm{ww} \cdot \mathrm{h}^{-1}$ (where $\mathrm{ww}=$ wet weight), or about $30 \%$ higher than values previously reported in the literature. Features of these recent studies include larger carbohydrate intakes (e.g. 1.0$1.8 \mathrm{~g} \cdot \mathrm{kg}^{-1} \mathrm{BM} \cdot \mathrm{h}^{-1}$ ) and repeated small feedings (e.g. intake every $15-60 \mathrm{~min}$ ) rather than single or several large meals. Unfortunately, because these studies did not make a direct comparison between glycogen storage and different amounts of carbohydrate and different feeding schedules, it is difficult to draw final conclusions about optimal carbohydrate intake in the early recovery phase. Nevertheless, the results of other studies (van Loon et al., 2000; Jentjens et al., 2001) suggest that the threshold for early glycogen recovery $(0-4 \mathrm{~h})$ is reached by a carbohydrate feeding schedule that provides $1.2 \mathrm{~g} \cdot \mathrm{kg}^{-1} \mathrm{BM} \cdot \mathrm{h}^{-1}$, based on the failure to increase muscle glycogen storage when extra energy (protein) was consumed.

\section{Timing of carbohydrate intake}

The highest rates of muscle glycogen storage occur during the first hour after exercise (Ivy et al., 1988a), due to activation of glycogen synthase by glycogen depletion (Wojtaszewski et al., 2001), and exerciseinduced increases in insulin sensitivity (Richter et al., 1988) and permeability of the muscle cell membrane to glucose. Carbohydrate feeding immediately after exercise appears to take advantage of these effects, as shown by higher rates of glycogen storage $\left(7.7 \mathrm{mmol} \cdot \mathrm{kg}^{-1} \mathrm{ww} \cdot \mathrm{h}^{-1}\right)$ during the first $2 \mathrm{~h}$ of recovery, slowing thereafter to the more typical rates of storage $\left(4.3 \mathrm{mmol} \cdot \mathrm{kg}^{-1} \mathrm{ww} \cdot \mathrm{h}^{-1}\right)$ (Ivy et al., 1988a). The most important finding of this study, however, is that failure to consume carbohydrate in the immediate phase of post-exercise recovery leads to very low rates of glycogen restoration until feeding occurs (Ivy et al., 1988a). Therefore, early intake of carbohy- 
drate after strenuous exercise is valuable because it provides an immediate source of substrate to the muscle cell to start effective recovery, as well as taking advantage of a period of moderately enhanced glycogen synthesis. Although early feeding may be important when there is only $4-8 \mathrm{~h}$ between exercise sessions (Ivy et al., 1988a), it may have less impact over a longer recovery period. For example, Parkin and co-workers (1997) found no difference in glycogen storage after 8 and $24 \mathrm{~h}$ of recovery whether carbohydrate-rich eating was begun immediately after exercise or delayed for $2 \mathrm{~h}$ (see Fig. 2). Overall it would appear that when the interval between exercise sessions is short, the athlete should maximize the effective recovery time by beginning carbohydrate intake as soon as possible. However, when longer recovery periods are available, athletes can choose their preferred meal schedule as long as total carbohydrate intake goals are achieved. It is not always practical to consume substantial meals or snacks immediately after the finish of a strenuous workout.

Whether carbohydrate is best consumed in large meals or as a series of snacks has also been studied. Studies examining 24-h recovery have found that restoration of muscle glycogen is the same whether a given amount of carbohydrate is fed as two or seven meals (Costill et al., 1981), or as four large meals or 16 one-hourly snacks (Burke et al., 1996). In the latter study, similar muscle glycogen storage was achieved despite marked differences in blood glucose and insulin profiles over $24 \mathrm{~h}$ (Burke et al., 1996). In contrast, very high rates of glycogen synthesis during the first 4-6 h of recovery have been reported when large amounts of carbohydrate were fed at 15-30 min intervals (Doyle et al., 1993; van Hall et al., 2000; van Loon et al., 2000; Jentjens et al., 2001), and attributed to the higher sustained insulin and glucose profiles achieved by such a feeding protocol. However, as previously noted, these outcomes were compared with other literature values of post-exercise glycogen restoration rather than directly tested against a control amount of carbohydrate fed in less frequent meals. One way to reconcile these apparently conflicting results is to propose that the effects of enhanced insulin and glucose concentrations on glycogen storage are most important during the first hours of recovery or when total carbohydrate intake is below the threshold of maximal glycogen storage. However, during longer periods of recovery or when total carbohydrate intake is above this threshold, manipulations of plasma substrates and hormones within physiological ranges do not add further benefit.

In summary, it would appear that meeting total carbohydrate requirements is more important than the pattern of intake, at least for long-term recovery, and the athlete is advised to choose a food schedule that is practical and comfortable. A more frequent intake of smaller snacks may be useful in overcoming the gastric

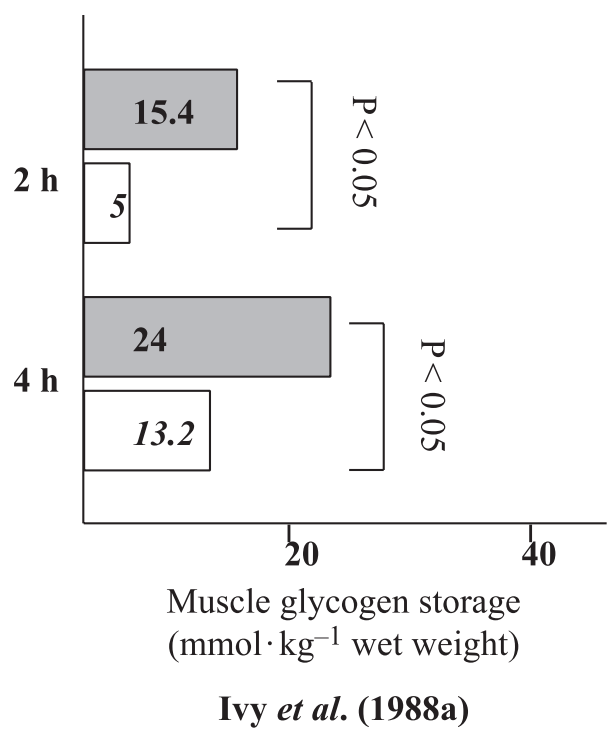

Early feeding

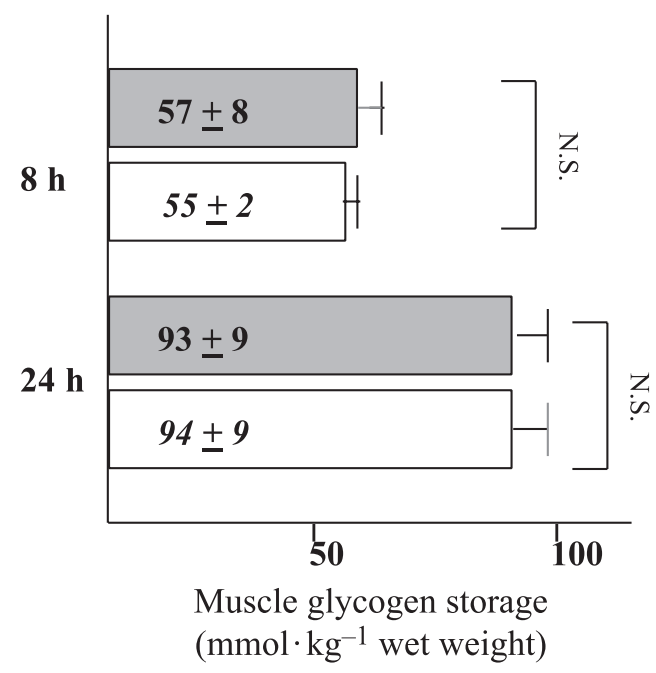

Parkin et al. (1997)

Delayed feeding $(2 h)$

Fig. 2. Timing of carbohydrate intake and glycogen storage. Delaying intake of carbohydrate until $2 \mathrm{~h}$ after the finish of a prolonged exercise session has a significant effect on short recovery periods (up to 6-8 h). Since effective refuelling does not occur until substantial amounts of carbohydrate are consumed, recovery after $4 \mathrm{~h}$ is impaired with delayed feeding compared with intake of the same amount of carbohydrate immediately after exercise and during recovery (Ivy et al., 1988a). When recovery periods are long enough $(8-24 \mathrm{~h})$, immediate intake of carbohydrate provides no further enhancement of glycogen storage as long as total carbohydrate intake is adequate (Parkin et al., 1997). 
discomfort often associated with eating large amounts of bulky high-carbohydrate foods, but may also provide direct benefits to glycogen storage during the early recovery phase.

\section{Type of carbohydrate intake}

Since glycogen storage is influenced both by insulin and a rapid supply of glucose substrate, it is logical that carbohydrate sources with a moderate to high glycaemic index (GI) would enhance post-exercise refuelling. This hypothesis has been confirmed in the case of single nutrient feedings of mono- and disaccharides; intake of glucose and sucrose after prolonged exercise both produce higher rates of muscle glycogen recovery than the low GI sugar, fructose (Blom et al., 1987). Unfortunately, early investigations of real foods (Costill et al., 1981; Roberts et al., 1988) used the structural classification of 'simple' and 'complex or starchy' carbohydrates to construct recovery diets; the conflicting results of these studies are probably due to the failure to achieve a real or consistent difference in the glycaemic index of the diets. The first fully reported comparison of foods based on published GI values found greater glycogen storage during $24 \mathrm{~h}$ of postexercise recovery with a carbohydrate-rich diet based on high GI foods compared with an identical amount of carbohydrate eaten in the form of low GI foods (Burke et al., 1993). However, the magnitude of increase in glycogen storage $(\sim 30 \%)$ was substantially greater than the difference in 24-h blood glucose and insulin profiles; the meal consumed immediately after exercise produced a large glycaemic and insulinaemic response, independent of the glycaemic index of the carbohydrate consumed, which overshadowed the differences in response to the rest of the diet. Other studies have confirmed an exaggerated glycaemic response to carbohydrate consumed immediately after exercise compared with the same feeding consumed at rest; this occurs as a result of greater gut glucose output and greater hepatic glucose escape (Rose et al., 2001). Increased muscle glucose uptake also occurs under these conditions, favouring glycogen storage. In summary, although it would appear that high GI carbohydrate foods achieve better post-exercise glycogen storage, this cannot be totally explained in terms of an enhanced glucose and insulin response.

An additional mechanism to explain less efficient glycogen storage with low GI carbohydrate-rich foods is that a considerable amount of the carbohydrate in these foods may be malabsorbed (Wolever et al., 1986; Jenkins et al., 1987). Indeed, Joszi and co-workers (1996) theorized that the poor digestibility of a high amylose starch mixture (low GI) was responsible for lower muscle glycogen storage observed during $13 \mathrm{~h}$ of post-exercise recovery compared with intake of glucose, maltodextrins and a high amylopectin starch (all high GI). They observed that indigestible carbohydrate forms provide a poor substrate for muscle glycogen resynthesis and overestimate the available carbohydrate consumed by individuals (Joszi et al., 1996). This issue requires further study in relation to real foods. Nevertheless, a study of chronic exposure to a lower GI diet in recreationally active people found a decline in muscle glycogen storage over 30 days compared both with pretrial values and values at the end of a high GI trial (Kiens and Richter, 1996). Thus, it would appear prudent to allow low GI foods to play only a minor role in post-exercise recovery meals; this is generally the case in Western eating patterns.

\section{Effect of gender}

Most studies of glycogen storage have been conducted with males, based on the assumption that the results will also apply to female athletes. There is some evidence that the menstrual status of female athletes affects glycogen storage, with greater storage of glycogen occurring during the luteal phase rather than the follicular phase (Nicklas et al., 1989; Hackney et al., 1994). Several studies of carbohydrate loading (i.e. prolonged glycogen storage) have provided direct or indirect evidence that female athletes are less responsive than their male counterparts (Tarnopolsky et al., 1995; Walker et al., 2000). However, the criticism of at least one study is that a methodology that simply requires individuals to increase carbohydrate intake as a proportion of 'usual' (self-reported) energy intake will result in a considerably smaller increase in carbohydrate intake, both in absolute amounts and relative to body mass, for females who are restrained eaters (Tarnopolsky et al., 1995). A further study by this group of workers found that female athletes needed to increase both carbohydrate and energy intake before a significant increase in glycogen storage was achieved (Tarnopolsky et al., 2001). Regarding the acute recovery period, female athletes in the mid-follicular phase of their menstrual cycle have produced identical rates of glycogen storage to male athletes after intakes of matched amounts (per kilogram of body mass) of carbohydrate or a carbohydrate-protein drink (Tarnopolsky et al., 1997).

\section{Effect of energy intake and co-ingestion of other nutrients}

It would appear that the relationship between carbohydrate intake and glycogen storage is underpinned by consideration of total energy intake (Tarnopolsky et al., 2001). The simplest way to consider this relationship is 
that dietary intake must provide for the body's immediate fuel requirements as well as storage opportunities. It is likely that during energy restriction, greater proportions of available carbohydrate substrates (e.g. dietary carbohydrate) are oxidized to meet immediate energy needs, whereas carbohydrate consumed during a period of energy balance or surplus may be available for storage within the muscle and liver. But it is also possible that the co-ingestion of other macronutrients, either present in carbohydrate-rich foods or consumed at the same meal, may have additional effects on muscle glycogen storage, independently of their effect on increasing total energy intake. While this hypothesis has not been tested systematically, factors that might directly or indirectly affect glycogen storage include the provision of gluconeogenic substrates, as well as effects on digestion, insulin secretion or the satiety of meals. The co-ingestion of protein with carbohydrate meals has received most attention in terms of glycogen recovery and has provided a source of some debate, with some studies reporting both an increase in glycogen storage when protein is added to a carbohydrate feeding (Zawadzki et al., 1992; van Loon et al., 2000; Ivy et al., 2002) and others finding no effect (Tarnopolsky et al., 1997; Roy and Tarnopolsky, 1998; Carrithers et al., 2000; van Hall et al., 2000).

Many of the conflicting results among studies, however, can probably be explained by differences in experimental design, including the frequency of supplementation, and the amounts of carbohydrate and protein provided. For example, in studies demonstrating that the addition of protein to a carbohydrate supplement will enhance muscle glycogen storage, feeding intervals of $2 \mathrm{~h}$ were used (Zawadzki et al., 1992; Ivy et al., 2002). Those studies that did not demonstrate a benefit of protein used feeding intervals of 15-30 min (Tarnopolsky et al., 1997; Carrithers et al., 2000; van Hall et al., 2000; Jentjens et al., 2001) and generally fed a high total amount of carbohydrate (van Hall et al., 2000; Jentjens et al., 2001), though in some studies a low amount of protein (Tarnopolsky et al., 1997; Carrithers et al., 2000). Regardless of the differences in experimental design, most evidence suggests that feeding a high amount of carbohydrate at frequent intervals negates the benefits of added protein. However, the evidence is compelling that the co-ingestion of protein with carbohydrate will increase the efficiency of muscle glycogen storage when the amount of carbohydrate ingested is below the threshold for maximal glycogen synthesis or when feeding intervals are more than $1 \mathrm{~h}$ apart (Zawadzki et al., 1992; Ivy et al., 2002; van Loon et al., 2000). The effectiveness of protein to enhance muscle glycogen storage appears limited to the first hour after supple- mentation (Ivy et al., 2002). As illustrated in Fig. 3, glycogen storage during the first $40 \mathrm{~min}$ of recovery after exercise was twice as fast after a carbohydrateprotein feeding than after an isoenergetic carbohydrate feeding, and four times faster than after a carbohydrate feeding of the same carbohydrate concentration. This trend also continued following the second feeding $2 \mathrm{~h}$ into recovery. These results have important implications for sports that have very short recovery periods during competition, such as soccer and ice hockey.

It is still uncertain whether the enhanced rates of glycogen storage due to co-ingestion of protein and carbohydrate may be achieved via the increased insulin response from protein per se, or as a result of the increase in energy intake. Thus it is prudent to conclude at this time that the presence of other macronutrients with carbohydrate feedings does not substantially alter muscle glycogen synthesis when total carbohydrate intake is at the level for the glycogen storage threshold. However, when the athlete's energy intake or food availability does not allow them to consume such amounts of carbohydrate, the presence of protein in post-exercise meals and snacks may enhance overall glycogen recovery. In fact, intake of protein in recovery meals is recommended to enhance net protein balance, tissue repair and adaptations involving synthesis of new proteins (see Tipton and Wolfe, 2004). The consumption of excessively large amounts of protein and fat in an athlete's diet, however,

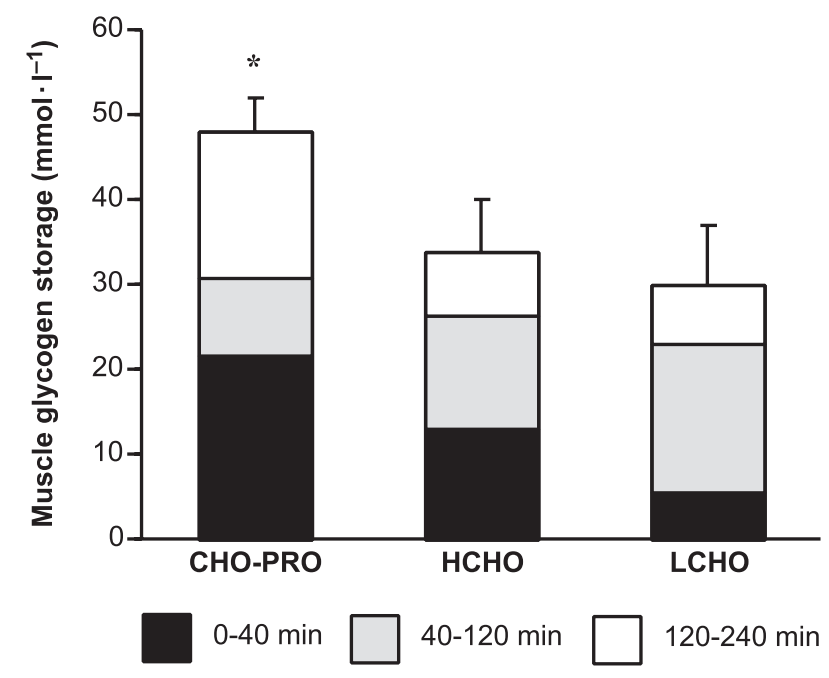

Fig. 3. Muscle glycogen storage following co-ingestion of carbohydrate and protein. Muscle glycogen storage at $0-40$, 40-120 and 120-240 min of recovery from an exhaustive cycling exercise. Treatments were carbohydrate-protein (CHO-PRO), isocaloric carbohydrate $(\mathrm{HCHO})$ and isocarbohydrate (LCHO) supplements provided immediately after exercise and after $2 \mathrm{~h}$ of exercise. *Significantly different than $\mathrm{HCHO}$ and LCHO (Ivy et al., 2002). 
is discouraged because it may displace carbohydrate foods within the athlete's energy requirements and gastric comfort, thereby indirectly interfering with glycogen storage by preventing adequate carbohydrate intake.

Alcohol is another nutrient of interest in terms of glycogen recovery, since there is evidence that some athletes, particularly in team sports, consume alcohol in large amounts in the post-exercise period (Burke et al., 2003). Rat studies have shown that intragastric administration of alcohol interferes with glycogen storage during $30 \mathrm{~min}$ of recovery from high-intensity exercise in oxidative but not non-oxidative fibres (Peters et al., 1996). Separate studies of $8 \mathrm{~h}$ and $24 \mathrm{~h}$ of recovery in well-trained cyclists who consumed alcohol immediately after an exercise bout showed that muscle glycogen storage was impaired during both periods when alcohol was used for isoenergetic displacement of carbohydrate intake from the recovery diet (Burke et al., 1996). Evidence for a direct effect of elevated blood alcohol concentrations on muscle glycogen synthesis was unclear, but it appeared that if an immediate impairment of glycogen synthesis existed, it might be compensated by adequate carbohydrate intake and a longer recovery period (Burke et al., 1996). It is likely that the most important effects of alcohol intake on glycogen resynthesis are indirect - by interfering with the athlete's ability, or interest, to achieve the recommended amounts of carbohydrate required for optimal glycogen restoration. Athletes are therefore encouraged to follow the guidelines for sensible use of alcohol in sport (Burke and Maughan, 2000), in conjunction with the well-supported recommendations for recovery eating.

\section{Update on guidelines for carbohydrate needs for daily training}

Previously developed dietary guidelines for athletes have been unanimous in their recommendation of high carbohydrate intakes in the everyday or training diet, based on the perceived benefits of promoting optimal recovery of muscle glycogen stores between training sessions (Devlin and Williams, 1991; Ekblom and Williams, 1994; Maughan and Horton, 1995; ACSM et al., 2000). An update on nutritional strategies to achieve this goal is summarized in Table 2, but before this can be accepted as a key principle of the proposed new guidelines of the International Olympic Committee, it is important to recognize that the advice has been criticized on two separate accounts. The first criticism is the apparent failure of athletes to achieve such carbohydrate-rich diets in training (Noakes, 1997), with the rationale that if it were advantageous to
Table 2. Revised guidelines for the intake of $\mathrm{CHO}$ in the everyday or training diets of athletes.

\section{Recommendations for}

- Athletes should aim to achieve carbohydrate intakes to meet the fuel requirements of their training programme and to optimize restoration of muscle glycogen stores between workouts. General recommendations can be provided, but should be fine-tuned with individual consideration of total energy needs, specific training needs and feedback from training performance:

- Immediate recovery after exercise $(0-4 \mathrm{~h}): 1.0$ $1.2 \mathrm{~g} \cdot \mathrm{kg}^{-1} \cdot \mathrm{h}^{-1}$ consumed at frequent intervals

- Daily recovery: moderate duration/low-intensity training: $5-7 \mathrm{~g} \cdot \mathrm{kg}^{-1} \cdot \mathrm{day}^{-1}$

- Daily recovery: moderate to heavy endurance training: $7-12 \mathrm{~g} \cdot \mathrm{kg}^{-1} \cdot$ day $^{-1}$

- Daily recovery: extreme exercise programme $(4-6+\mathrm{h}$ per day): $10-12+\mathrm{g} \cdot \mathrm{kg}^{-1} \cdot \mathrm{day}^{-1}$

- It is valuable to choose nutrient-rich carbohydrate foods and to add other foods to recovery meals and snacks to provide a good source of protein and other nutrients. These nutrients may assist in other recovery processes and, in the case of protein, may promote additional glycogen recovery when carbohydrate intake is suboptimal or when frequent snacking is not possible.

- When the period between exercise sessions is $<8 \mathrm{~h}$, the athlete should begin carbohydrate intake as soon as practical after the first workout to maximize the effective recovery time between sessions. There may be some advantages in meeting carbohydrate intake targets as a series of snacks during the early recovery phase.

- During longer recovery periods $(24 \mathrm{~h})$, the athlete should organize the pattern and timing of carbohydrate-rich meals and snacks according to what is practical and comfortable for their individual situation. There is no difference in glycogen synthesis when liquid or solid forms of carbohydrate are consumed.

- Carbohydrate-rich foods with a moderate to high glycaemic index provide a readily available source of carbohydrate for muscle glycogen synthesis, and should be the major carbohydrate choices in recovery meals.

- Adequate energy intake is important for optimal glycogen recovery; the restrained eating practices of some athletes, particularly females, make it difficult to meet carbohydrate intake targets and to optimize glycogen storage from this intake.

\section{Recommendations against}

- Guidelines for carbohydrate (or other macronutrients) should not be provided in terms of percentage contributions to total dietary energy intake. Such recommendations are neither user-friendly nor strongly related to the muscle's absolute needs for fuel.

- The athlete should not consume excessive amounts of alcohol during the recovery period, since it is likely to interfere with their ability or interest to follow guidelines for post-exercise eating. The athlete should follow sensible drinking practices at all times, but especially in the period after exercise. 
training adaptations and performance, we would expect athletes to follow the practice. A review of the dietary surveys of serious athletes published since the announcement of the 1991 sports nutrition guidelines found that the mean values for the reported daily carbohydrate intake of athletes was about $50-55 \%$ of total energy intake (Burke et al., 2001) compared with the $60-70 \%$ of energy intake suggested in the guidelines (Devlin and Williams, 1991). However, the apparent mismatch between sports nutrition guidelines and the real-life dietary patterns of athletes can largely be explained as a result of confusion arising from the terminology used to make these recommendations (Burke et al., 2001).

The 1991 summary guidelines for carbohydrate intake for athletes (Devlin and Williams, 1991) follow the traditional terminology used in population dietary guidelines, where recommendations for the intake of macronutrients are expressed as the proportion of dietary energy that they should typically contribute. However, population guidelines for carbohydrate result from taking a number of issues into account for a generic group of people (e.g. meeting requirements for protein, achieving benefits from reducing fat intake) rather than trying to meet specific muscle fuel needs for a specialized subgroup or, more particularly, for an individual. The athlete's fuel needs are better estimated from more direct information, such as the carbohydrate intake required to optimize glycogen recovery, or the carbohydrate expenditure of the training programme. Such estimates of carbohydrate needs should be provided relative to the body mass of the athlete to roughly account for the size of the muscle mass that must be fuelled. General guidelines derived from such information are suggested in Table 2, but should also be considered as 'ball-park' ranges that can be finetuned for the individual athlete with more specific knowledge of their actual training programme, past and present response to training and their total energy budget. The dietary surveys of athletes published over the past decade show mean values of reported daily carbohydrate intake to be 7.6 and $5.8 \mathrm{~g} \cdot \mathrm{kg}^{-1} \mathrm{BM}$ for male endurance and non-endurance athletes, respectively, and 5.7 and $4.6 \mathrm{~g} \cdot \mathrm{kg}^{-1} \mathrm{BM}$ for female endurance and non-endurance athletes, respectively (Burke et al., 2001). These values suggest the daily carbohydrate intakes of the typical male athlete fall within the suggested ranges for fuel needs (Table 2), especially if the usual feature of under-reporting on dietary records is taken into account. Of course, these mean estimates do not guarantee that all athletic groups or specific athletes meet these recommended intakes or, indeed, meet their actual fuel requirements; such determinations can only be made on an individual basis. However, female athletes are at higher risk of carbohydrate intakes below these ranges, largely as a result of lower energy intakes.

The use of energy ratio terminology to recommend or assess the carbohydrate intake of athletes should be actively discouraged. Examination of dietary survey data from endurance-trained athletes (1970-2001) provides clear evidence that carbohydrate intake expressed as a percentage of dietary energy and intakes expressed as grams relative to body mass are not interchangeable concepts (see Fig. 4). Among groups of male athletes, there is evidence of a loose but positive correlation between reported intakes of carbohydrate (grams per kilogram) and the energy contributed by carbohydrate in the diet. In other words, male athletes who change their eating patterns to increase the energy contribution of carbohydrate in their diets are likely to increase their carbohydrate intake per kilogram of body mass; however, targeting a particular carbohydrate: energy ratio will not guarantee that specific fuel needs based on grams per kilogram of body mass are achieved. In contrast, there is no correlation between the

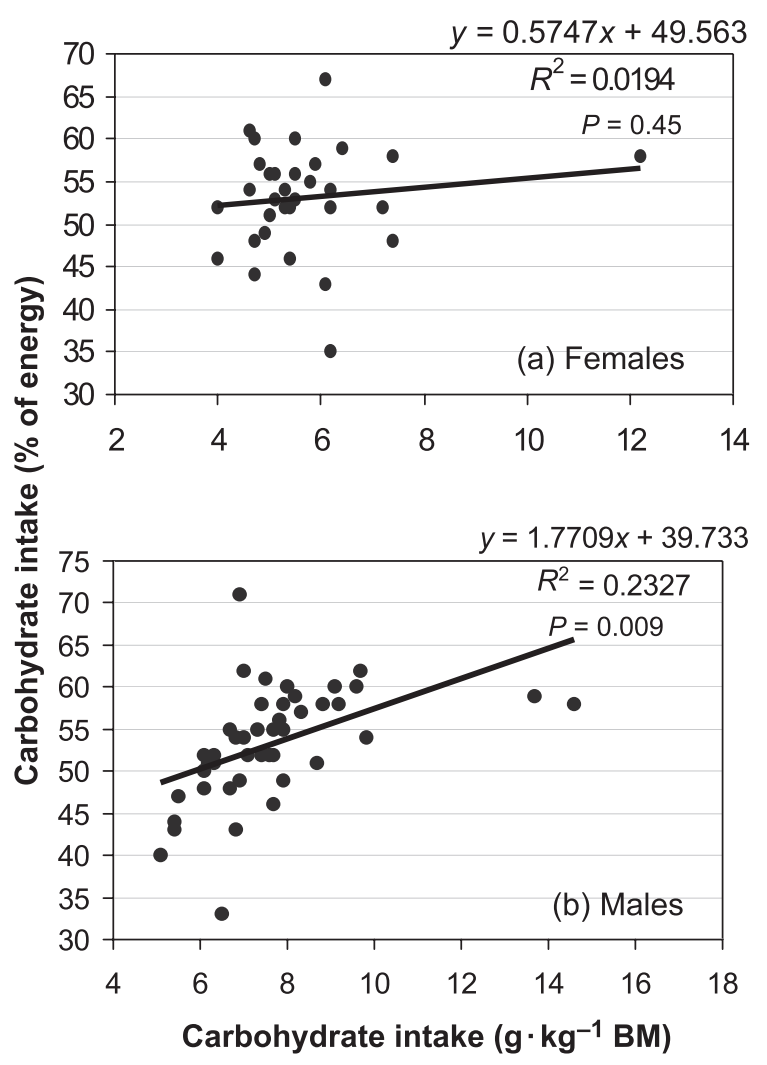

Fig. 4. Relationship between reported mean daily carbohydrate intake, represented as $\mathrm{g} \cdot \mathrm{kg}^{-1} \mathrm{BM}$ and percent of energy, from dietary surveys of groups of serious endurance athletes (taken from Burke et al., 2001). Each data point represents the mean value reported for a separate group of athletes. 
carbohydrate:energy ratio in the diets reported by female endurance athletes and their total carbohydrate intake (grams per kilogram of body mass), due to the confounding issue of restricted energy intake in some individuals or groups.

\section{Do high carbohydrate diets really enhance train- ing adaptations?}

The second, and more important, criticism of the recommendation for high carbohydrate intakes lies with the failure of longitudinal studies to show clear and consistent benefits to training adaptations and performance compared with moderate carbohydrate diets (see Table 3). Although there is clear evidence of superior recovery of muscle glycogen with a higher carbohydrate intake, a minority of the available studies show enhancement of training outcomes (Simonsen et al., 1991; Achten et al., 2003). The most recent of these studies creates considerable interest with its finding that a higher carbohydrate intake was able to reduce, but not entirely prevent, the 'over-reaching' syndrome that can occur when a period of intensified training is undertaken (Achten et al., 2003). However, it is curious that benefits from high carbohydrate eating have not been a universal outcome from training studies. Several methodological issues are important, including the overlap between what is considered a 'moderate' and 'high' carbohydrate in various studies. Other important issues are whether sufficient time was allowed for differences in the training responses of athletes to lead to significant differences in the study performance outcome, and whether the protocol used to measure performance was sufficiently reliable to detect small but real improvements that would be of significance to a competitive athlete (Hopkins et al., 1999).

One possible conclusion from the available studies of chronic dietary patterns and exercise performance is that athletes can adapt to the lower muscle glycogen stores resulting from moderate carbohydrate intakes such that it does not impair training or competition outcomes. However, no study has shown that moderate carbohydrate intakes promote superior training adaptations and performance compared with higher carbohydrate diets. Clearly, further research needs to be undertaken, using specialized and rigorous protocols, to examine further the issue of chronic carbohydrate intake in heavily training athletes. Since such studies require painstaking control over a long period, it is not surprising that there are few in the literature. In the meantime, although the lack of clear literature support is curious, the evidence from studies of acute carbohydrate intake and exercise performance remains our best estimate of the chronic carbohydrate needs of athletes.

\section{Fat as a muscle substrate}

Since the adipose fat stores in the body are relatively large even in the leanest athlete, the replacement of the fat oxidized during an exercise session has not been thought to limit performance. The 1991 consensus statement did not make any special recommendations in relation to dietary fat and recovery. Since that time, however, and in spite of methodological problems of undertaking measurements of this substrate (Watt et al., 2002), there has been an increased interest in the utilization of intramuscular triacylglycerol (IMTG) stores during exercise and their replacement during recovery. There is now consensus that IMTGs provide a potentially important energy source for the contracting muscle (Watt et al., 2002), and emerging evidence that the consumption of a high carbohydrate/low fat diet in the recovery period after prolonged exercise may fail to provide for efficient recovery of this substrate (Decombaz et al., 2001; van Loon et al., 2003). Furthermore, one of the studies reviewed in the previous section identified that a moderate carbohydrate diet allowed a two-fold increase in IMTG stores compared with a high carbohydrate diet (Vogt et al., 2003). The importance of the replenishment of IMTG for the performance of exercise is presently unknown, but is discussed in greater detail in the context of training adaptations by Spriet and Gibala (2004). The present review will conclude with a brief exploration of the possibility that chronic adaptation to high fat diets during the training phase may confer an advantage to performance by decreasing the muscle's reliance on its limited glycogen stores as an exercise fuel

\section{Effect of high fatllow carbohydrate diets on training adaptations and performance}

The effect of consuming a high fat/low carbohydrate diet for 1-3 days, while continuing to exercise, is to lower resting muscle and liver glycogen stores, resulting in reduced exercise capacity and endurance (Bergstrom et al., 1967; Starling et al., 1997; Pitsiladis and Maughan, 1999). This impairment in performance is likely to result from a combination of the premature depletion of (lowered) muscle glycogen stores and the absence of any worthwhile increase in the capacity for fat utilization during exercise to compensate for the reduction in available carbohydrate fuel. In contrast, there is evidence that a longer period ( $>7$ days) of adherence to a high fat/low carbohydrate diet causes metabolic adaptations that substantially enhance fat 
Table 3. Longitudinal studies comparing high carbohydrate $(\mathrm{CHO})$ intakes $(\mathrm{HCHO})$ and moderate carbohydrate intakes $(\mathrm{MCHO})$ on training adaptation and performance of athletes undertaking intensive training

\begin{tabular}{|c|c|c|c|c|c|c|}
\hline Study & Athletes & Duration of study (days) & $\begin{array}{l}\text { CHO intake } \\
\left(\mathrm{g} \cdot \mathrm{kg}^{-1} \cdot \mathrm{day}^{-1}\right)\end{array}$ & Effect on muscle glycogen & Performance protocol & Performance advantage with $\mathrm{HCHO}$ \\
\hline Costill et al. (1988) & $\begin{array}{l}\text { Well-trained } \\
\text { swimmers }(12 \mathrm{M})\end{array}$ & $\begin{array}{l}10 \text { days; participants self- } \\
\text { selected into two dietary } \\
\text { groups (8 HCHO and } 4 \\
\text { MCHO) }\end{array}$ & 8.2 vs 5.3 & $\begin{array}{l}\text { Declined in } \mathrm{MCHO} \text {; maintained in } \\
\mathrm{HCHO}\end{array}$ & $\begin{array}{l}\text { Training: doubling of usual } \\
1.5 \mathrm{~h} \cdot \text { day }^{-1} \text { training programme } \\
\text { Performance battery: power (swim } \\
\text { bench); } 2 \times 25 \text { yards freestyle swim } \\
\text { with } 2-3 \text { min recovery interval; } \\
\dot{V} \mathrm{O}_{2 \text { max }} \text { in pool; swimming } \\
\text { efficiency at submaximal pace }\end{array}$ & $\begin{array}{l}\text { No for final performance. No } \\
\text { difference in } 25 \text { yards swim, swim } \\
\text { power or } V \mathrm{O}_{2 \max } \text { from pre-trial or } \\
\text { between groups. However, stroke } \\
\text { efficiency reduced in MCHO } \\
\text { Yes for training performance. } \\
\text { MCHO group reported 'chronic } \\
\text { fatigue' during training programme }\end{array}$ \\
\hline Lamb et al. (1990) & $\begin{array}{l}\text { Well-trained } \\
\text { swimmers }(14 \mathrm{M})\end{array}$ & 9 days; crossover design & 12.1 vs 6.5 & Not available & $\begin{array}{l}2 \times \text { daily training sessions. Intervals } \\
\text { over a variety of distances }+1500 \mathrm{~m} \\
\text { and } 3000 \mathrm{~m} \text { timed for afternoon } \\
\text { sessions during last } 5 \text { days }\end{array}$ & $\begin{array}{l}\text { No. No difference in mean } \\
\text { swimming times over range of } \\
\text { distances between diets }\end{array}$ \\
\hline Kirwan et al. (1988) & $\begin{array}{l}\text { Well-trained runners } \\
(10 \mathrm{M})\end{array}$ & 5 days: crossover design & 8.0 vs 3.9 & $\begin{array}{l}\text { Declined in both groups but greater } \\
\text { reduction in MCHO }\end{array}$ & $\begin{array}{l}\text { Training increased by } 150 \% \text { for } 5 \\
\text { days. Economy tested on treadmill } \\
\text { at two speeds on days } 4 \text { and } 6 \\
\text { Overnight fasted }\end{array}$ & $\begin{array}{l}\text { Yes. Reduction in running economy } \\
\text { with MCHO }\end{array}$ \\
\hline Sherman et al. (1993) & $\begin{array}{l}\text { Trained runners } \\
(2 \times 9 \mathrm{M})\end{array}$ & $\begin{array}{l}7 \text { days; parallel group } \\
\text { design }\end{array}$ & 10 vs 5 & $\begin{array}{l}\text { Declined in } \mathrm{MCHO} \text {; maintained in } \\
\mathrm{HCHO}\end{array}$ & $\begin{array}{l}2 \times \text { time to exhaustion on a } \\
\text { treadmill at } 80 \% \mathrm{VO}_{2 \max } \text { with } 5 \text { min } \\
\text { recovery period. Trials undertaken at } \\
\text { end of day after } 1 \mathrm{~h} \text { training }\end{array}$ & $\begin{array}{l}\text { No. No difference in endurance } \\
\text { between groups during either run. } \\
\text { Sum time }=613 \pm 36 \mathrm{~s} \text { and } \\
560 \pm 106 \mathrm{~s} \text { for } \mathrm{MCHO} \text { and } \mathrm{HCHO} \\
\text { respectively (not significant) }\end{array}$ \\
\hline Achten et al. (2003) & $\begin{array}{l}\text { Well-trained runners } \\
(7 \mathrm{M})\end{array}$ & $\begin{array}{l}4 \text { days }+7 \text { days intensified } \\
\text { training; crossover design }\end{array}$ & 8.5 vs 5.4 & $\begin{array}{l}\text { Decrease in muscle glycogen } \\
\text { utilization during training sessions } \\
\text { at } 58 \text { and } 77 \% \mathrm{VO}_{2 \max } \text { during } \\
\mathrm{MCHO} \text { trial compared with } \mathrm{HCHO}\end{array}$ & $\begin{array}{l}\text { Pre-load }+8-\mathrm{km} \text { treadmill time-trial } \\
\text { on days } 1,5,8 \text { and } 11 ; 16-\mathrm{km} \text { road } \\
\text { time-trial on days } 6,7,9 \text { and } 10 \\
\text { Overnight fasted }\end{array}$ & $\begin{array}{l}\text { Yes. Intensified training led to } \\
\text { deterioration of } 8-\mathrm{km} \text { time-trial } \\
\text { performance by } 61 \mathrm{~s} \text { in HCHO and } \\
155 \mathrm{~s} \text { in } \mathrm{MCHO} \text {, and deterioration } \\
\text { in } 16-\mathrm{km} \text { time-trial performance in } \\
\mathrm{MCHO} \text { only. HCHO reduces } \\
\text { symptoms of over-reaching during } \\
\text { intensified training compared with } \\
\mathrm{MCHO} \text {, but does not prevent it } \\
\text { entirely }\end{array}$ \\
\hline Simonsen et al. (1991) & $\begin{array}{l}\text { Collegiate rowers } \\
(12 \mathrm{M}, 10 \mathrm{~F})\end{array}$ & $\begin{array}{l}28 \text { days; parallel group } \\
\text { design }\end{array}$ & 10 vs 5 & $\begin{array}{l}\text { MCHO allowed maintenance of } \\
\text { muscle glycogen stores, while } \\
\text { HCHO allowed an increase in stores }\end{array}$ & $\begin{array}{l}3 \times 2500 \text {-m rowing ergometer time- } \\
\text { trial with } 8 \text { min recovery interval } \\
\text { undertaken on days } 1,3 \text { and } 5 \text { of } \\
\text { each week. Trials undertaken at } \\
\text { evening workout }\end{array}$ & $\begin{array}{l}\text { Yes. Power output maintained } \\
\text { during ergometer rowing time-trial } \\
\text { over the course of MCHO, leading } \\
\text { to overall improvement of } 1.6 \% \text { at } \\
\text { end of } 4 \text { weeks. Improvement in } \\
\text { power output in HCHO over same } \\
\text { time-frame }=10.7 \%\end{array}$ \\
\hline
\end{tabular}


Table 3. (continued)

\begin{tabular}{|c|c|c|c|c|c|c|}
\hline Study & Athletes & Duration of study (days) & $\begin{array}{l}\text { CHO intake } \\
\left(\mathrm{g} \cdot \mathrm{kg}^{-1} \cdot \mathrm{day}^{-1}\right)\end{array}$ & Effect on muscle glycogen & Performance protocol & Performance advantage with $\mathrm{HCHO}$ \\
\hline Sherman et al. (1993) & $\begin{array}{l}\text { Trained cyclists } \\
(2 \times 9 \mathrm{M})\end{array}$ & $\begin{array}{l}7 \text { days; parallel group } \\
\text { design }\end{array}$ & 10 vs 5 & $\begin{array}{l}\text { Declined in MCHO; maintained in } \\
\text { HCHO }\end{array}$ & $\begin{array}{l}2 \times \text { time to exhaustion on cycle } \\
\text { ergometer at } 80 \% \dot{V} \mathrm{O}_{2 \max } \text { with } \\
5 \text { min recovery period. Trials } \\
\text { undertaken at end of day after } 1 \mathrm{~h} \\
\text { training }\end{array}$ & $\begin{array}{l}\text { No. No difference between groups } \\
\text { on endurance during either bout. } \\
\text { Sum time }=550 \pm 85 \mathrm{~s} \text { and } \\
613 \pm 45 \mathrm{~s} \text { for } \mathrm{MCHO} \text { and } \mathrm{HCHO} \\
\text { respectively (not significant) }\end{array}$ \\
\hline Vogt et al. (2003) & $\begin{array}{l}\text { Well-trained } \\
\text { duathletes }(11 \mathrm{M})\end{array}$ & 35 days; crossover design & 6.9 vs 3.6 & Maintained on both diets & $\begin{array}{l}\dot{V} \mathrm{O}_{2 \text { max, }} \text { cycling time-trial } \\
\text { undertaken after progressive } \\
\text { submaximal pre-load; outdoor } 21- \\
\mathrm{km} \text { run (all undertaken on separate } \\
\text { days). Trials undertaken post-meal } \\
\text { (composition of meal varied with } \\
\text { dietary treatment) }\end{array}$ & $\begin{array}{l}\text { No. No difference in aerobic } \\
\text { capacity, cycling time-trial power or } \\
\text { half-marathon run time between } \\
\text { diets (e.g. } 21-\mathrm{km} \text { run }=80 \mathrm{~min} \\
12 \mathrm{~s} \pm 86 \mathrm{~s} \text { and } 80 \mathrm{~min} 24 \mathrm{~s} \pm 82 \mathrm{~s} \\
\text { for } \mathrm{HCHO} \text { and } \mathrm{MCHO} \text { ) }\end{array}$ \\
\hline
\end{tabular}

Abbreviations: $\mathrm{M}=$ male; $\mathrm{F}=$ female. 
oxidation during exercise and, to a large extent, compensate for the reduced carbohydrate availability. In fact, many 'popular' diet books claim that 'fat loading' strategies enhance performance capabilities of endurance and ultra-endurance athletes by making them better able to 'tap into body fat stores' (Sears, 1995).

Studies in which trained individuals have been exposed to a high fat diet ( $>60-65 \%$ of dietary energy [E]) for 5-28 days show markedly higher rates of fat oxidation and reduced rates of muscle glycogen use during submaximal exercise compared with consumption of an isoenergetic high carbohydrate diet, despite the already enhanced capacity for fat oxidation expected in the trained individual (Phinney et al., 1983; Lambert et al., 1994; Goedecke et al., 1999). However, examination of the performance outcomes from these studies shows either a lack of a performance benefit (see Table 4) or methodological/design flaws that require a conservative and cautious interpretation of the results (for a review, see Burke and Hawley, 2002). For example, while the study of Phinney et al. (1983), in which five well-trained cyclists were tested before and after 4 weeks of adaptation to a high fat $(85 \% \mathrm{E}) /$ low carbohydrate $\left(<20 \mathrm{~g} \cdot\right.$ day $\left.^{-1}\right)$ diet, is frequently cited in support of performance enhancement after fat-loading, the participants actually achieved similar endurance times under both experimental conditions. Furthermore, the group results were skewed by an abnormally large improvement in the performance of one cyclist: the remaining four cyclists showed little change or, indeed, an impairment of exercise capacity after the high fat treatment.

An important finding of Goedecke et al. (1999), who showed that matched groups showed similar training effects after 2 weeks of a high fat diet or an isoenergetic high carbohydrate diet, was that the adaptations to the high fat diet ( $65 \%$ of dietary energy) were achieved in as little as 5 days. If fat adaptation can be demonstrated as an effective strategy for performance enhancement for athletes, by itself or as part of a 'dietary periodization' protocol that subsequently replaces muscle glycogen stores (Burke and Hawley, 2002), then brief exposure is more practical and better tolerated by most individuals than more prolonged periods of intervention. Therefore, it is best considered as a pre-competition strategy (see Hargreaves et al., 2004) rather than a long-term training practice. Indeed, studies in which previously sedentary individuals undertook training while following a high fat or high carbohydrate diet indicate that prolonged exposure of more than 4 weeks to a high fat diet causes an impairment of training adaptations and subsequent performance (Helge et al., 1996, 1998).

\section{Summary and future directions for research}

There is clear evidence that adequate carbohydrate intake is important for the restoration of muscle glycogen stores, and that other dietary strategies related to the timing of intake, type of carbohydrate source or addition of other nutrients may either directly enhance the rate of glycogen recovery or improve the practical achievement of carbohydrate intake targets. Education strategies that focus on post-exercise glycogen restoration can be made clearer to athletes by providing recommendations for carbohydrate intake in terms of grams per kilogram of body mass rather than percentage of dietary energy intake. The role of specific strategies to recover muscle fat stores utilized during exercise is unclear at this time. It is difficult to demonstrate the translation of chronic strategies of daily recovery of muscle glycogen stores through high carbohydrate intakes into superior training adaptations and performance using conventional intervention studies. However, the results of acute studies clearly show that enhanced carbohydrate availability is of benefit to endurance capacity and performance. This serves as a reasonable basis to continue to advise athletes to consume adequate carbohydrate to meet the daily fuel needs of their training programmes, or at least to optimize their intake of carbohydrate within eating patterns that meet their energy needs and other aspects of healthy nutrition. Guidelines based on our present knowledge are summarized in Table 2. Major areas for future research include:

1. For situations where adequate carbohydrate can be consumed:

- At what intake of carbohydrate is the threshold for glycogen storage reached over the first $4 \mathrm{~h}$ of postexercise recovery?

- Is there an advantage during the first $4 \mathrm{~h}$ of recovery to consuming carbohydrate in the form of frequent snacks rather than a single bolus or large meals?

- Are low GI carbohydrate foods less suitable for post-exercise recovery, particularly when available carbohydrate is taken into account? What is the mechanism involved? To what extent can they be included in recovery meals?

2. For situations where energy restriction causes suboptimal carbohydrate intake:

- Is there any difference in glycogen storage from a suboptimal intake of carbohydrate in terms of manipulating:

- Frequency of intake?

- High versus low GI carbohydrate to manipulate insulin response to meals?

- Addition of other nutrients (particularly protein)? 
Table 4. Longitudinal studies comparing long-term adaptation to high fat/low carbohydrate (HFAT) intakes and moderate to high carbohydrate (CHO) intakes on endurance performance in well-trained individuals.

\begin{tabular}{|c|c|c|c|c|}
\hline Study & Athletes & Fat adaptation protocol & Performance protocol & Performance advantage with HFAT \\
\hline $\begin{array}{l}\text { Phinney et } \\
\text { al. (1983) }\end{array}$ & $\begin{array}{l}\text { Well-trained cyclists } \\
(5 \mathrm{M}) \text {; crossover } \\
\text { design with order } \\
\text { effect (control diet } \\
\text { first) }\end{array}$ & $\begin{array}{l}28 \text { days; } \mathrm{CHO}(57 \% \text { carbohydrate), } \\
\text { then } 28 \text { days } \mathrm{HFAT}\left(\text { fat }^{2}=85 \% \mathrm{E} \text {, }\right. \\
\text { carbohydrate }<20 \mathrm{~g} \cdot \text { day }^{-1} \text { ) }\end{array}$ & $\begin{array}{l}\text { Cycling time to fatigue at } 80 \% \mathrm{VO}_{2 \max } \\
\text { Overnight-fasted }+ \text { no carbohydrate intake during } \\
\text { exercise }\end{array}$ & $\begin{array}{l}\text { No. No difference in time to fatigue between trials ( } 151 \\
\text { vs } 147 \text { min for HFAT vs CHO). However, group data } \\
\text { skewed by performance of one participant who increased } \\
\text { time to fatigue by } 156 \% \text { on the fat trial }\end{array}$ \\
\hline $\begin{array}{l}\text { O'Keefe } e t \\
\text { al. (1989) }\end{array}$ & $\begin{array}{l}\text { Moderately trained } \\
\text { cyclists }(7 \mathrm{~F}) \text {; } \\
\text { crossover design }\end{array}$ & $\begin{array}{l}7 \text { days; HFAT }(\mathrm{fat}=59 \% \mathrm{E} \\
\left.\text { carbohydrate }=1.2 \mathrm{~g} \cdot \mathrm{kg}^{-1} \mathrm{BM}\right) ; \\
\mathrm{CHO}\left(\text { carbohydrate }=6.4 \mathrm{~g} \cdot \mathrm{kg}^{-1} \mathrm{BM}\right)\end{array}$ & $\begin{array}{l}\text { Cycling time to fatigue at } 80 \% \mathrm{VO}_{2 \max } \\
3-4 \text { h post-meal, no carbohydrate intake during exercise }\end{array}$ & $\begin{array}{l}\text { No. In fact, performance deterioration with HFAT. } \\
\text { Time to fatigue reduced by } 47 \% \text { on HFAT trial }\end{array}$ \\
\hline $\begin{array}{l}\text { Lambert et } \\
\text { al. (1994) }\end{array}$ & $\begin{array}{l}\text { Well-trained cyclists } \\
(5 \mathrm{M}) \text {; crossover } \\
\text { design }\end{array}$ & $\begin{array}{l}14 \text { days; HFAT }(\mathrm{fat}=67 \% \mathrm{E}, \\
\left.\text { carbohydrate }=17 \% \mathrm{E}^{*}\right) ; \mathrm{CHO} \\
\left(\text { carbohydrate }=74 \% \mathrm{E}^{*}\right)\end{array}$ & $\begin{array}{l}\text { Cycling time to fatigue at } 60 \% \dot{V} \mathrm{O}_{2 \max } \text { (preceded by } \\
\text { Wingate test and time to fatigue at } 90 \% \mathrm{~V}_{2 \text { max }} \text { ) } \\
\text { Overnight-fasted }+ \text { no carbohydrate intake during exercise }\end{array}$ & $\begin{array}{l}\text { Yes. Time to fatigue increased by } 87 \% \text { on HFAT trial. } \\
\text { No significant differences in performance between trials } \\
\text { on preceding high-intensity cycle tests }\end{array}$ \\
\hline $\begin{array}{l}\text { Goedecke } e t \\
\text { al. (1999) }\end{array}$ & $\begin{array}{l}\text { Well-trained cyclists } \\
(2 \times 8 \mathrm{M}) \text {; parallel } \\
\text { group design }\end{array}$ & $\begin{array}{l}15 \text { days; HFAT }(\text { fat }=69 \% \mathrm{E} \\
\left.\text { carbohydrate }=2.2 \mathrm{~g} \cdot \mathrm{kg}^{-1} \mathrm{BM}\right) ; \\
\left.\text { CHO (carbohydrate }=5.5 \mathrm{~g} \cdot \mathrm{kg}^{-1} \mathrm{BM}\right)\end{array}$ & $\begin{array}{l}150 \text { min cycling at } 70 \% \dot{V} \mathrm{O}_{2 \max }+\sim 60 \text {-min time-trial } \\
\text { (time to complete } 40 \mathrm{~km}) \\
\text { MCT intake } 1.5 \mathrm{~h} \text { pre-event }(\sim 14 \mathrm{~g}) ; \mathrm{MCT} \\
\left(0.3 \mathrm{~g} \cdot \mathrm{kg}^{-1} \cdot \mathrm{h}^{-1}\right) \text { and carbohydrate }\left(0.8 \mathrm{~g} \cdot \mathrm{kg}^{-1} \cdot \mathrm{h}^{-1}\right) \\
\text { during exercise } \\
\text { Performance measured at } 0,5,10 \text { and } 15 \text { days }\end{array}$ & $\begin{array}{l}\text { No. Time-trial performance improved over time in both } \\
\text { groups as a result of training protocol. Significant } \\
\text { improvements seen in both groups by day } 10 \text {, but no } \\
\text { difference in mean improvement between groups }\end{array}$ \\
\hline $\begin{array}{l}\text { Rowlands } \\
\text { and Hopkins } \\
\text { (2002) }\end{array}$ & $\begin{array}{l}\text { Well-trained cyclists } \\
(7 \mathrm{M}) \text {; crossover } \\
\text { design }\end{array}$ & $\begin{array}{l}14 \text { days; HFAT (fat }=66 \% \mathrm{E}, \\
\left.\text { carbohydrate } \sim 2.4 \mathrm{~g} \cdot \mathrm{kg}^{-1} \mathrm{BM}\right) ; \mathrm{HCHO} \\
\text { (carbohydrate } \sim 8.6 \mathrm{~g} \cdot \mathrm{kg}^{-1-} \mathrm{BM}, \\
70 \% \text { carbohydrate) }\end{array}$ & $\begin{array}{l}\text { 5-h cycling protocol, including } 15 \text {-min time- } \\
\text { trial }+ \text { incremental test }+100 \text {-km time-trial } \\
H F A T=\text { high fat pre-event meal; } H C H O=\text { high } \\
\text { carbohydrate pre-event meal; both } 0.8 \mathrm{~g} \cdot \mathrm{kg}^{-1} \cdot \mathrm{h}^{-1} \\
\text { carbohydrate during ride }\end{array}$ & $\begin{array}{l}\text { Yes: Submaximal intensity exercise } \\
\text { No: Higher intensity exercise } \\
\text { Relative to baseline testing: HCHO showed small non- } \\
\text { significant decreases in both } 15 \text {-min time-trial and 100- } \\
\text { km time-trial. HFAT showed larger but non-significant } \\
\text { decrease in } 15 \text {-min time-trial but small non-significant } \\
\text { improvement in } 100 \text {-km time-trial }\end{array}$ \\
\hline
\end{tabular}

Abbreviations: $\mathrm{M}=$ male: $\mathrm{F}=$ female; $\dot{V} \mathrm{O}_{2 \max }=$ maximal oxygen uptake. ${ }^{*} \mathrm{~g} \cdot \mathrm{kg}^{-1} \mathrm{BM}$ intakes unavailable. 


\section{References}

Achten, J., Halson, S., Mosely, L., Rayson, M.P., Casey, A. and Jeukendrup, A.E. (2003). Effect of diet on symptoms of overreaching in runners during a period of intensified training. Medicine and Science in Sports and Exercise, 35(suppl.), S211.

Adamo, K.B. and Graham, T.E. (1998). Comparison of traditional measurements with macroglycogen and proglycogen analysis of muscle glycogen. Fournal of Applied Physiology, 84, 908-913.

Adamo, K.B., Tarnopolsky, M.A. and Graham, T.E. (1998). Dietary carbohydrate and postexercise synthesis of proglycogen and macroglycogen in human skeletal muscle. American Fournal of Physiology: Endocrinology and Metabolism, 275, E229-E234.

Alonso, M.D., Lomako, J., Lomako, W.M. and Whelan, W.J. (1995). A new look at the biogenesis of glycogen. FASEB fournal, 9, 1126-1137.

American College of Sports Medicine, American Dietetic Association and Dietitians of Canada (2000). Nutrition and athletic performance. Medicine and Science in Sports and Exercise, 32, 2130-2145.

Bergstrom, J., Hermansen, L., Hultman, E. and Saltin, B. (1967). Diet, muscle glycogen and physical performance. Acta Physiologica Scandinavica, 71, 140-150.

Blom, P.C.S., Hostmark, A.T., Vaage, O., Vardel, K.R. and Maehlum, S. (1987). Effect of different post-exercise sugar diets on the rate of muscle glycogen synthesis. Medicine and Science in Sports and Exercise, 19, 491-496.

Burke, L.M. and Hawley, J.A. (2002). Effects of short-term fat adaptation on metabolism and performance of prolonged exercise. Medicine and Science in Sports and Exercise, 34, 1492-1498.

Burke, L.M. and Maughan, R.J. (2000). Alcohol in sport. In Nutrition in Sport (edited by R.J. Maughan), pp. 405-414. Oxford: Blackwell Science.

Burke, L.M., Collier, G.R. and Hargreaves, M. (1993). Muscle glycogen storage after prolonged exercise: the effect of the glycemic index of carbohydrate feedings. Fournal of Applied Physiology, 75, 1019-1023.

Burke, L.M., Collier, G.R., Beasley, S.K., Davis, P.G., Fricker, P.A., Heeley, P., Walder, K. and Hargreaves, M. (1995). Effect of coingestion of fat and protein with carbohydrate feedings on muscle glycogen storage. Fournal of Applied Physiology, 78, 2187-2192.

Burke, L.M., Collier, G.R., Davis, P.G., Fricker, P.A., Sanigorski, A.J. and Hargreaves, M. (1996). Muscle glycogen storage after prolonged exercise: effect of the frequency of carbohydrate feedings. American fournal of Clinical Nutrition, 64, 115-119.

Burke, L.M., Cox, G.R., Cummings, N.K. and Desbrow, B. (2001). Guidelines for daily carbohydrate intake: do athletes achieve them? Sports Medicine, 31, 267-299.

Burke, L.M., Collier, G.R., Broad, E.M., Davis, P.G., Martin, D.T., Sanigorski, A.J. and Hargreaves, M. (2003). The effect of alcohol intake on muscle glycogen storage following prolonged exercise. Fournal of Applied Physiology, 95, 983-990.
Carrithers, J.A., Williamson, D.L., Gallagher, P.M., Godard, M.P., Schulze, K.E. and Trappe, S.W. (2000). Effects of postexercise carbohydrate-protein feedings on muscle glycogen restoration. Fournal of Applied Physiology, 88, 1976-1982.

Costill, D.L., Sherman, W.M., Fink, W.J., Maresh, C., Witten, M. and Miller, J.M. (1981). The role of dietary carbohydrates in muscle glycogen resynthesis after strenuous running. American fournal of Clinical Nutrition, 34, 1831-1836.

Costill, D.L., Flynn, M.G., Kirwan, J.P., Houmard, J.A., Mitchell, J.B., Thomas, R.T. and Park, S.H. (1988). Effects of repeated days of intensified training on muscle glycogen and swimming performance. Medicine and Science in Sports and Exercise, 20, 249-254.

Costill, D.L., Pascoe, D.D., Fink, W.J., Robergs, R.A., Barr, S.I. and Pearson, D. (1990). Impaired muscle glycogen resynthesis after eccentric exercise. Fournal of Applied Physiology, 69, 46-50.

Coyle, E.F. (1991). Timing and method of increased carbohydrate intake to cope with heavy training, competition and recovery. Fournal of Sports Sciences, 9(suppl.), 2952.

Coyle, E.F. (1995). Substrate utilization during exercise in active people. American fournal of Clinical Nutrition, 61 (suppl.), 968S-979S.

Coyle, E.F. (2004). Fluid and fuel intake during exercise. Fournal of Sports Sciences, 22, 39-55.

Coyle, E.F., Jeukendrup, A.E., Oseto, M.C., Hodgkinson, B.J. and Zderic, T.W. (2001). Low-fat diet alters intramuscular substrates and reduces lipolysis and fat oxidation during exercise. American fournal of Physiology: Endocrinology and Metabolism, 280, E391-E398.

Decombaz, J., Schmitt, B., Ith, M., Decarli, B., Diem, P., Kreis, R., Hoppeler, H. and Boesch, C. (2001). Postexercise fat intake repletes intramyocellular lipids but no faster in trained than in sedentary subjects. American Fournal of Physiology, 281, R760-R769.

Devlin, J.T. and Williams, C. (eds) (1991). Final consensus statement: foods, nutrition and sports performance. Fournal of Sports Sciences, 9(suppl.), iii.

Doyle, J.A., Sherman, W.M. and Strauss, R.L. (1993). Effects of eccentric and concentric exercise on muscle glycogen replenishment. Fournal of Applied Physiology, 74, 1848-1855.

Ekblom, B. and Williams, C. (eds) (1994). Final consensus statement: foods, nutrition and soccer performance. Fournal of Sports Science, 12(suppl.), S3.

Goedecke, J.H., Christie, C., Wilson, G., Dennis, S.C., Noakes, T.D., Hopkins, W.G. and Lambert, E.V. (1999). Metabolic adaptations to a high-fat diet in endurance cyclists. Metabolism, 48, 1509-1517.

Hackney, A.C., McCracken-Compton, M.A. and Ainsworth, B. (1994). Substrate responses to submaximal exercise in the midfollicular and midluteal phases of the menstrual cycle. International fournal of Sport Nutrition, 4, 299308. 
Hargreaves, M. (1999). Metabolic responses to carbohydrate ingestion: effects on exercise performance. In Perspectives in Exercise Science and Sports Medicine (edited by D.R. Lamb and R. Murray), pp. 93-124. Carmel, IN: Cooper.

Hargreaves, M., Hawley, J.A. and Jeukendrup, A.E. (2004). Pre-exercise carbohydrate and fat ingestion: effects on metabolism and performance. Fournal of Sports Sciences, 22, 31-38.

Helge, J.W., Richter, E.A. and Kiens, B. (1996). Interaction of training and diet on metabolism and endurance during exercise in man. Fournal of Physiology, 492, 293-306.

Helge, J.W., Wulff, B. and Kiens, B. (1998). Impact of a fatrich diet on endurance in man: role of the dietary period. Medicine and Science in Sports and Exercise, 30, 456-461.

Hopkins, W.G., Hawley, J.A. and Burke, L.M. (1999). Design and analysis of research on sport performance enhancement. Medicine and Science in Sports and Exercise, 31, 472-485.

Ivy, J.L., Katz, A.L., Cutler, C.L., Sherman, W.M. and Coyle, E.F. (1988a). Muscle glycogen synthesis after exercise: effect of time of carbohydrate ingestion. Fournal of Applied Physiology, 64, 1480-1485.

Ivy, J.L., Lee, M.C., Brozinick, J.T. and Reed, M.J. (1988b). Muscle glycogen storage after different amounts of carbohydrate ingestion. Fournal of Applied Physiology, 65, 2018-2023.

Ivy, J.L., Goforth, H.W., Damon, B.D., McCauley, T.R., Parsons, E.C. and Price, T.B. (2002). Early post-exercise muscle glycogen recovery is enhanced with a carbohydrate-protein supplement. Fournal of Applied Physiology, 93, 1337-1344.

Jenkins, D.J.A., Cuff, D., Wolever, T.M.S., Knowland, D., Thompson, L., Cohen, Z. and Prokipchuk, E. (1987). Digestibility of carbohydrate foods in an ileostomate: relationship to dietary fibre, in vitro digestibility, and glycemic responses. American fournal of Gastroenterology, 82, 709-717.

Jentjens, R.L., van Loon, L.J.C., Mann, C.H., Wagenmakers, A.J.M. and Jeukendrup, A.E. (2001). Addition of protein and amino acids to carbohydrates does not enhance postexercise muscle glycogen synthesis. Fournal of Applied Physiology, 91, 839-846.

Jozsi, A.C., Trappe, T.A., Starling, R.D., Goodpaster, B., Trappe, S.W., Fink, W.J. and Costill, D.L. (1996). The influence of starch structure on glycogen resynthesis and subsequent cycling performance. International fournal of Sports Medicine, 17, 373-378.

Kiens, B. and Richter, E.A. (1996). Types of carbohydrate in an ordinary diet affect insulin action and muscle substrates in humans. American fournal of Clinical Nutrition, 63, 47-53.

Kiens, B. and Richter, E.A. (1998). Utilization of skeletal muscle triacylglycerol during postexercise recovery in humans. American Fournal of Physiology: Endocrinology and Metabolism, 275, E332-E337.

Kirwan, J.P., Costill, D.L., Mitchell, J.B., Houmard, J.A., Flynn, M.G., Fink, W.J. and Beltz, J.D. (1988). Carbohydrate balance in competitive runners during successive days of intense training. Fournal of Applied Physiology, 65, 2601-2606.
Lamb, D.R., Rinehardt, K.F., Bartels, R.L., Sherman, W.M. and Snook, J.T. (1990). Dietary carbohydrate and intensity of interval swim training. American fournal of Clinical Nutrition, 52, 1058-1063.

Lambert, E.V., Speechly, D.P., Dennis, S.C. and Noakes, T.D. (1994). Enhanced endurance in trained cyclists during moderate intensity exercise following 2 weeks adaptation to a high fat diet. European fournal of Applied Physiology, 69, 287-293.

Maughan, R.J. and Horton, E.S. (eds) (1995). Final consensus statement: current issues in nutrition in athletics. Fournal of Sports Sciences, 13(suppl.), S1.

Nicklas, B.J., Hackney, A.C. and Sharp, R.L. (1989). The menstrual cycle and exercise: performance, muscle glycogen, and substrate responses. International fournal of Sports Medicine, 10, 264-269.

Noakes, T.D. (1997). Challenging beliefs: ex Africa semper aliquid novi. Medicine and Science in Sports and Exercise, 29, 571-590.

O'Keefe, K.A., Keith, R.E., Wilson, G.D. and Blessing, D.L. (1989). Dietary carbohydrate intake and endurance exercise performance of trained female cyclists. Nutrition Research, 9, 819-830.

Parkin, J.A.M., Carey, M.F., Martin, I.K., Stojanovska, L. and Febbraio, M.A. (1997). Muscle glycogen storage following prolonged exercise: effect of timing of ingestion of high glycemic index food. Medicine and Science in Sports and Exercise, 29, 220-224.

Peters, T.J., Nikolovski, S., Raja, G.K., Palmer, N. and Fournier, P.A. (1996). Ethanol acutely impairs glycogen repletion in skeletal muscle following high intensity short duration exercise in the rat. Addiction Biology, 1, 289295.

Phinney, S.D., Bistrian, B.R., Evans, W.J., Gervino, E. and Blackburn, G.L. (1983). The human metabolic response to chronic ketosis without caloric restriction: preservation of submaximal exercise capacity with reduced carbohydrate oxidation. Metabolism, 32, 769-776.

Piehl Aulin, K., Soderlund, K. and Hultman, E. (2000). Muscle glycogen resynthesis rate in humans after supplementation of drinks containing carbohydrates with low and high molecular masses. European fournal of Applied Physiology, 81, 346-351.

Pitsiladis, Y.P. and Maughan, R.J. (1999). The effects of exercise and diet manipulation on the capacity to perform prolonged exercise in the heat and in the cold in trained humans. Fournal of Physiology, 517, 919-930.

Richter, E.A., Mikines, K.J., Galbo, H. and Kiens, B. (1989). Effects of exercise on insulin action in human skeletal muscle. Fournal of Applied Physiology, 66, 876885.

Roberts, K.M., Noble, E.G., Hayden, D.B. and Taylor, A.W. (1988). Simple and complex carbohydrate-rich diets and muscle glycogen content of marathon runners. European Fournal of Applied Physiology, 57, 70-74.

Roden, M. and Shulman, G.I. (1999). Applications of NMR spectroscopy to study muscle glycogen metabolism in man. Annual Review of Medicine, 50, 277-290. 
Rose, A.J., Howlett, K., King, D.S. and Hargreaves, M. (2001). Effect of prior exercise on glucose metabolism in trained men. American Fournal of Physiology: Endocrinology and Metabolism, 281, E766-E771.

Rowlands, D.S. and Hopkins, W.G. (2002). Effects of highfat and high-carbohydrate diets on metabolism and performance in cycling. Metabolism, 51, 678-690.

Roy, B.D. and Tarnopolsky, M.A. (1998). Influence of differing macronutrient intakes on muscle glycogen resynthesis after resistance exercise. Fournal of Applied Physiology, 84, 890-896.

Saris, W.H.M., Van Erp-Baart, M.A., Brouns, F., Westerterp, K.R. and ten Hoor, F. (1989). Study on food intake and energy expenditure during extreme sustained exercise: the Tour de France. International fournal of Sports Medicine, 10(suppl. 1), S26-S31.

Sears, B. (1995). The Zone Diet: A Dietary Road Map. New York: Regan Books.

Shearer, J. and Graham, T.E. (2002). New perspectives on the storage and organization of muscle glycogen. Canadian Fournal of Applied Physiology, 27, 179-203.

Sherman, W.M., Doyle, J.A., Lamb, D.R. and Strauss, R.H. (1993). Dietary carbohydrate, muscle glycogen, and exercise performance during $7 \mathrm{~d}$ of training. American Fournal of Clinical Nutrition, 57, 27-31.

Simonsen, J.C., Sherman, W.M., Lamb, D.R., Dernbach, A.R., Doyle, J.A. and Strauss, R. (1991). Dietary carbohydrate, muscle glycogen, and power output during rowing training. Fournal of Applied Physiology, 70, 15001505.

Spriet, L.L. and Gibala, M.J. (2004). Nutritional strategies to influence adaptations to training. Fournal of Sports Sciences, 22, 127-141.

Starling, R.D., Trappe, T.A., Parcell, A.C., Kerr, C.G., Fink, W.J. and Costill, D.L. (1997). Effects of diet on muscle triglyceride and endurance performance. Fournal of Applied Physiology, 82, 1185-1189.

Tarnopolsky, M.A., Atkinson, S.A., Phillips, S.M. and MacDougall, J.D. (1995). Carbohydrate loading and metabolism during exercise in men and women. fournal of Applied Physiology, 78, 1360-1368.

Tarnopolsky, M.A., Bosman, M., MacDonald, J.R., Vandeputte, D., Martin, J. and Roy, B.D. (1997). Postexercise protein-carbohydrate and carbohydrate supplements increase muscle glycogen in men and women. Fournal of Applied Physiology, 83, 1877-1883.
Tarnopolsky, M.A., Zawada, C., Richmond, L.B., Carter, S., Shearer, J., Graham, T. and Phillips, S.M. (2001). Gender differences in carbohydrate loading are related to energy intake. Fournal of Applied Physiology, 91, 225-230.

Tipton, K.D. and Wolfe, R.R. (2004). Protein and amino acids. Fournal of Sports Sciences, 22, 65-79.

Van Hall, G., Shirreffs, S.M. and Calbert, J.A.L. (2000). Muscle glycogen resynthesis during recovery from cycle exercise: no effect of additional protein ingestion. Fournal of Applied Physiology, 88, 1631-1636.

Van Loon, L.J.C., Saris, W.H.M., Kruijshoop, M. and Wagenmakers, A.J.M. (2000). Maximizing postexercise muscle glycogen synthesis: carbohydrate supplementation and the application of amino acid or protein hydrolysate mixtures. American fournal of Clinical Nutrition, 72, 106111.

Van Loon, L.J., Schrauwen-Hinderling, V.B., Koopman, R., Wagenmakers, A.J., Hesselink, M.K., Schaart, G., Kooi, M.E. and Saris, W.H. (2003). Influence of prolonged cycling and recovery diet on intramuscular triglyceride content in trained males. American fournal of Physiology: Endocrinology and Metabolism, 285, E804-E811.

Vogt, M., Puntschart, A., Howald, H., Mueller, B., Mannhart, C., Gfeller-Tuescher, L., Mullis, P. and Hoppeler, H. (2003). Effects of dietary fat on muscle substrates, metabolism, and performance in athletes. Medicine and Science in Sports and Exercise, 35, 952-960.

Watt, M.J., Heigenhauser, G.J.F. and Spriet, L.L. (2002). Intramuscular triacylglycerol utilization in human skeletal muscle during exercise: is there a controversy? fournal of Applied Physiology, 93, 1185-1195.

Wojtaszewski, J.P.F., Nielson, P., Kiens, B. and Richter, E.A. (2001). Regulation of glycogen synthase kinase-3 in human skeletal muscle: effects of food intake and bicycle exercise. Diabetes, 50, 265-269.

Wolever, T.M.S., Cohen, Z., Thompson, L.U., Thorne, M.J., Jenkins, M.J.A., Propikchuk, E.J. and Jenkins, D.J.A. (1986). Ideal loss of available carbohydrate in man: comparison of a breath hydrogen method with direct measurement using a human ileostomy model. American fournal of Gastroenterology, 81, 115-122.

Zawadzki, K.M., Yaspelkis, B.B. and Ivy, J.L. (1992). Carbohydrate-protein complex increases the rate of muscle glycogen storage after exercise. Fournal of Applied Physiology, 72, 1854-1859. 